\title{
Dilemmas of Cultural Transmission
}

\author{
Mária Kováts-Németh \\ Faculty of Education, J. Selye University, Komárno, 94501, Slovakia
}

Copyright $(2016$ by authors, all rights reserved. Authors agree that this article remains permanently open access under the terms of the Creative Commons Attribution License 4.0 International License

\begin{abstract}
The fundamental problem of the $21^{\text {st }}$ century is that in the modern civilization the transmission of values is not stable. There is nothing, except for the natural sense of justice and some legal traditions, which would exercise selective power on social behavior. At a critical time in 1949 Albert Szent-Györgyi drew the attention to the fact that "education is one of the most important activities of mankind." Why do they question this in the $21^{\text {st }}$ century? We might assume that the reason is basically the loss of values which goes together with the successes reached through superficial knowledge; as well as the lack of the measure, the morality, the attitude to be followed; the appreciation of the European and typically Hungarian cultural heritages; and cultural transmission. Education science has an important role in the recreation of culture. In the first half of the $20^{\text {th }}$ century new pedagogical trends appeared and evolved in Europe and the United States. Their comparative evaluation could be helpful at the free choice of high standards.
\end{abstract}

Keywords Culture, Cultural Transmission, Value Theory, Cultural Pedagogy, Reform Pedagogy, Education, Literacy

\section{Introduction}

"The most important difference between us and the great apes is culture. Not the symbolic culture, which mostly lies inside our minds, but the one that exists outside of it. Culture shares the cognitive activity between many brains, and governs the thinking of its members...

We are a culturally bound species living in symbiosis with our own creations. We seek culture as birds seek wind. In return, culture shapes our minds the same way the sculptor shapes the material."

Donald is being quoted by Csaba Pléh, when he emphasizes that it is necessary for today's scientific world and its practice to aim at synthesis. It is exceptionally important, since nowadays we can talk about a tripolar, not a bipolar world. These three factors include: the psyche, the mental process, and development. The last one of these factors, development, incorporates evolution, culture, and ontogenesis. [1]
We own a many thousand years old cultural heritage, in the same way as all peoples possess their own unique one. Our common, but in the same way unique European culture consists of antiquity, Roman law and Christianity.

And what are common among the features of the Hungarian, Slovak, Polish and German cultures? They are literacy, and the way it is being transmitted. These cultures share the vision of the SCHOOL, which helps us learn how to speak "one language", the language of value systems. While being able to maintain our diversity, the SCHOOL enables us to understand each other, to stand for and spread our own values, and to be able to constantly renew them. It teaches us how to honor and value the science, art, faith and traditions - the unique culture of another people. It allows us to see that variety and diversity does not make us poorer, it enriches not only us, but ultimately Europe as well.

It is important, within our information abundant world or rather to say a world of overflowing information, not to stay insecure, but to use our values, inherited by thousands of years, as guidelines for confidence and security.

The school can help us to recognize these guidelines, only if it spreads and renews a curriculum as the basis of literacy, culture, and authentic literacy. The condition of this renewal is the synthesis of the culture to be acquired, as well as using the power of authenticity to point out the coherence between the aforementioned phenomena.

It is our most important task to discover and enrich the culture practiced by our ancestors. The guidance of Pope Benedict XVI should help us differentiate the relevant from the irrelevant. "The Book of Wisdom says: God handed over the world to our contentious interpretation. Knowing science is the adventure he left to us. In revelation, however, he reveals what is important for life and death." [2]

The European culture always kept a count of the ancient Eastern cultures. These include: the cuneiform clay tablets of Mesopotamia from $7^{\text {th }}$ millennium BC, the clerical church-schools established in the $4^{\text {th }}$ millennium; the Egyptian culture with its hieroglyph writing, the high quality training in not just clerkship but the natural sciences as well; Brahman - the Hindu upbringing, where cultural transmission is caste-specific; and the Chinese culture, which operated a school system in the $2^{\text {nd }}$ millennium $B C$, and which used the five holy books, compiled by Confucius 
in the $6^{\text {th }}$ century $\mathrm{BC}$, as the basis of the curriculum for the second level of public education.

\section{The Issue}

"The future of humanity depends on those people, who stand for the truth, and whose lives are being fulfilled with the high moral principles. These shall move their heart to self-devoted love." (Pope Saint John Paul II)

The fundamental problem of the $21^{\text {st }}$ century is that in the modern civilization the transmission of values is not stable. There is nothing, except for the natural sense of justice and some legal traditions, which would exercise selective power on social behavior. At a critical time in 1949 Albert Szent-Györgyi drew the attention to the fact that "education is one of the most important activities of mankind."

Why do they question this in the $21^{\text {st }}$ century? We might assume that the reason is basically the loss of values which goes together with the successes reached through superficial knowledge; as well as the lack of the measure, the morality, the attitude to be followed; the appreciation of the European and typically Hungarian cultural heritages; and cultural transmission.

Since the beginning of institutional education and even after pedagogy became an independent science, the essential question still is: What is the purpose and role of school? The purpose of school is: education and familiarization with the civilizational values, preservation, enrichment and renewal of the culture generation by generation. The purpose of education is "to enable individuals and through them the social community - nation and society - for moral development". This also means to enable people "to do good of free will", to which it is necessary to possess the virtues of self-control, truthfulness and love. [25] The familiarization and acquirement of civilizational values evolve in the process of education. In order to realize this purpose, we have to be familiar with the culture's fundamental factors and the aspects of selecting the cultural content of literacy to be transmitted as "curriculum". The purpose of education and pedagogy must be the transmission of the entire culture knowledge, faith, art, morality. In 2002 these four factors of culture were redefined by UNESCO, which are the same as those already maintained by pedagogical sciences in Europe, except the ones representing the materialist worldview. Unfortunately, the fundamental questions of cultural transmission are not being discussed adequately neither by the theory nor by the practice of science in the $21^{\text {th }}$ century.

A decisive perspective when selecting the culture for transmission is value theory. Today, the practice of this approach has been overshadowed. Educational purposes can only be formulated of highly ordered values - ideal values that serve as guidelines in our lives. Only humanities can transfer higher purposes; natural sciences provide the basis and help us to understand the world. Our task is to make the experts of educational politics and professionals realize that "the humanities and religion are the moral condition of the society." [3]

The main issue is the general uncertainty in the assessment of those factors determining cultural content, furthermore in determining fundamental values, especially in the case of former socialist countries. In the liberty ensured by democracy the respect and observance of rules and regulations has decreased. Many researchers prove that the values, types of behavior, and transmission of norms, developed during the history of humankind, are missing from modern society. This prevents the evolvement of a mature personality. [4] According to K. Lorenz growing up without having to face any failures will result in infantilism. [5]

The root of the problem lies in cultural transmission. Who are responsible for the mediation of culture? Are the responsible ones uncertain in their task of being in charge for the influences children receive through their path to adulthood? Or are their actions intentional in causing ambiguity and spreading unculturedness?

Sándor Márai left to us the following: "Heading eastward, Hungary is the last cultural area, where the European man has the same common fate with everything that represents the past, present and responsibility of European Christian literacy." Hungarians feel alike when listening to a lecture at Sorbonne in Paris, and the same spirit speaks to a Stockholmian entering the Esztergom Basilica as in the Uppsala Cathedral. "Western civilization in Hungary is not an import, but the elemental component of its past, present and the function of its role." Do we really teach and learn what our professional duty is? Or the vow taken at the ceremonial acceptance of the diploma is only a formality, meaning that not keeping it has no consequences at all? How could it involve responsibilities if it does not even cause a twinge of conscience? Nevertheless, our heritage is rich because the "Hungarian history of spiritual knowledge (Geisteswissenschaft) has always responded particularly and accountably to the big European questions." [6]

Consequently the press, radio, media, publishers, theatres, museums, and politics are at least as much responsible as the teacher.

How to teach what we do not know? Namely: What is the commonweal? Obviously, it cannot be propagated by neither the market, nor fashion. When they defined the notion of Europe, they believed that Europe stands on three pillars: the Greek philosophy, Roman law and Christian morality. "European identity is defined by intellectual and moral values". [7]

The educational content to be acquired is different in Europe than it is in America. Likewise, the knowledge and way of thinking about the world and people is various as well. This educational difference is also present inside Europe, mainly in the unique national features - despite the many common aspects of European nations. Certainly, these were approved by the various religious convictions at the beginning of the century.

Taking these into consideration, the formation of the "right thinking" is based on the acquisition of the elements 
of national literacy. They include the general moral and national factors as well. Therefore the ultimate purpose of education is to enable the acquisition of the aspects of national literacy. These impact on students' emotions and will as well, enriching and improving them simultaneously. In conclusion the viewpoints for selecting the curriculum are:

- the moral perspective (humanism), as moral character gives value for a man

- the national perspective, because the child needs to become part of the nation

- the utility perspective, for being able to hold on during "life struggles" [8]

\section{Dilemmas of Cultural Transmission}

Pedagogists of the 21 st century are surrounded with so much information that it is extremely difficult to orientate among them. Neither the theory nor the practice of science is adequately concerned with the fundamental questions of culture and cultural transmission. The observance and respect of the conventions and norms has declined in the liberalism that is secured by democracy. The result: insecurity in values, and in the actual, personality-shaping (pedagogical) content in the concepts of freedom independence - activeness. In addition, the knowledge of pedagogical schools is shallow, and half-literacy is growing.

The reason of cultural perplexity is the loss of qualitative cultural adaptation. In my study I would like to call the attention to the educational theories and concepts which appeared in the turn of the 19th and 20th century. Their searches for new roads are outstanding examples to people today in order to reconsider value-based educational purposes and tasks. Knowing and understanding cultural pedagogy that was based on value theory improves the orientation among the hierarchy of values - self-values and instrumental values - so the purpose of education would be determined by the ideal or eternal values. At the same time the contents and fields of educational tasks would be determined by the instrumental values - real and social which vary through generations. The educational principles of reform pedagogy are practical, aiming for daily needs independence, freedom, activeness - they are actual educational tasks, which mainly belong to the frame conditions of nurturing. Social concepts also demonstrate the degree of human value by identifying the characteristic indicator of being humane.

\subsection{The Task is the Renewal of Culture}

What is culture? "Culture is the complex of material and intellectual values established by humankind." [9] This basic premise is true, even for the production and mediation of culture in those historically and socially defined ages, during which the evaluation of contemporaries is not objective in light of human actions. The efficiency, continuity and value of human actions are proven by the subsequent generations. After more than 360 years, who would remember those envious ones of Apáczai, whispering lies into his ears? [10] Yet one is a less educated person, if one is not familiar with the scholar of his own homeland, representing the European and national culture. He published The Hungarian Encyclopedia, the first one in Hungary, including those elemental truths which still help us today in orienting in the world and in the selection of the content for general literacy.

Culture symbolizes some area or areas of education; the level and representation of literacy of any nation. We can observe this through the works of our ancestors. They produced something exemplary for the rise of the cultural literacy of the Hungarian nation. In the 1920s, for example, with the growing number of elementary schools via Kuno Klebelsberg's educational politics, from the new textbooks for the $5^{\text {th }}$ and $6^{\text {th }}$ graders, they learned about the importance of József baron Eötvös. He was a minister of culture, working for the extension of education, who established a law in 1868 for compulsory schooling. [11]

Culture represents the literacy of a certain individual; their general cultural awareness; their cultural identity; the culture of their behavior.

The colorful interpretation of culture might seem a problem only for the first sight. The fact that the material and intellectual culture is the result of certain people's and communities' actions can be considered as evident. The task for the people today is nothing else than the renewal of the culture.

In the $21^{\text {st }}$ century, just like in any other era, we face with several issues to which the resolutions are blocked by many controversies. The primary controversy lies in the examination of cultural factors, the selection of the content of education, and in the value-centered approach. Namely: Which are the values that the students of a given age need to acquire? Or, what are the primary elements of literacy?

In the theory of pedagogy of the $21^{\text {st }}$ century, there is no significant contradiction regarding the cultural transmission's principal constitutional frame, the school, neither in the fact, that cultural transmission progresses through education by learning. Albert Szent-Györgyi's following idea, however, is viewed by many doubts: "The future of mankind depends on education, on this changeable programmed system. The history of mankind reflects basically this gradual transition... It follows from the fact that education is one of the most important activities of mankind." [12]

\subsection{The Science of Cultural Transmission is Pedagogy: Nurturing and Education}

"We are a culturally bound species living in symbiosis with our own creations."

Pedagogy, the structure of educational sciences was developed during the $19^{\text {th }}-20^{\text {th }}$ century. Following the works of Herbart and his students, T. Ziller and W. Rein, it became 
publicly known and decisive, that children have to go through all the steps of cultural learning during their development. In other words, they have to accomplish the historical and cultural development. The teachable materials of the curricula - according to their level of cultural theory covered the general cultural-historical and national history, based on the antique culture and selected literary works. The aim: being familiar with the civilizational values, the cultural goods, and being able to process them; preserving, enriching and recreating the culture generation by generation. It was demonstrated by the humanistic, "emotion-centered" organization of the curriculum, which was incorporated with cultural pedagogical concepts. To accomplish this task, at the end of the $19^{\text {th }}$ century, scholars developed the structure of pedagogical science.

Pedagogy examines education as a social phenomenon. It explores the connections between a nation's historical development, life circumstances, educational methods, and educational structures. For this very reason, Ödön Weszely rightly states that the notion of pedagogy is expandable for the entire area of common education. This way pedagogy is not only an educational science, but the science of culture as well. Its task is:

- $\quad$ to preserve the treasures of common literacy;

- to determine how these treasures could became public domains;

- to transmit them for the next generation.

Pedagogy is not only the educational science of an individual, but the theoretical and practical transmission of common literacy; it is also the science of its organization. Both cultural learning and education are independent fields of pedagogy.

New pedagogical concepts, which appeared at the turn of the century, wished to achieve the moral development of the society with the value-based cultural pedagogy, and aimed at the improved education of the individual with the methods of new reform pedagogy, as well as the realization of social sensitivity.

At the end of the $19^{\text {th }}$ century, the establishment of the spiritual knowledge-based cultural pedagogy represented the renewal of culture in Central Europe. The basic principle of cultural pedagogy is that intellectual knowledge and literacy is what protects man from half-literacy and simplification; and the purpose of education could and should be formulated by the ideal and eternal values. The scholars of education of Central Europe agreed on this principle, and clearly stated that next to the educational purposes, which define ideal values, educational tasks should be established as well. They are based on real and social values, but may change through generations and societies.

Reform pedagogy aimed at the renewal of society with the fulfillment of personal independency and freedom. Social pedagogy was also born at the end of the $19^{\text {th }}$ century. Its main purpose was to provide education and common (general) literacy for every member of a given society.

At the end of the $20^{\text {th }}$ century Friedrich W. Kron summarized the cooperational network of pedagogical science. According to this, the co-sciences of PEDAGOGY (cooperation sciences) are the following: philosophy and theology, psychology and sociology, anthropology and medicine, biology, politics and ethnology. Based on the research methods in this correlation, Kron differentiates two basic schools: the school of spiritual knowledge and of social or empirically oriented sciences. He emphasizes that empirical research is the task of each pedagogical area, "but the necessity of philosophical reflection is unquestionable." [13]

In spite of the fact that empirical research is essential in every area, the high differentiation might endanger the main point. Therefore Kron's assertion, philosophical framework and value theory, is exceptionally important.

\section{Cultural Pedagogy - Focus on Values}

"...the morality at the end of the century is intensely decaying throughout the whole educated world. The reason of moral sinking can always be found in man, in human nature, in selfishness. The external circumstances only liberate these." [14]

By the end of the $21^{\text {st }}$ century, as a result of the revival of natural sciences, human thinking had entirely reshaped. The task of the school got expanded, therefore a primary goal was drafted: school should inform its students about things, relations, natural and moral laws, among which they would have to live. It was found that natural sciences should act as basis, while the humanities should provide an example in personal development. The debate about the importance, role, and primacy of the natural sciences and the humanities resulted in a standpoint, which defined the value-centered approach to the education of cultural transmission and education sciences. During the first half of the $20^{\text {th }}$ century, the theory and practice of the science of pedagogy throughout Europe was defined by an image of man which is based on ideal values, and an approach to literacy which promoted it.

The scientific life of Central Europe was influenced mainly by the work of German pedagogical scientists, such as W. Dilthey, E. Spranger, and G. Kerschensteiner.

Wilhelm Dilthey was the professor of the University of Berlin between 1882 and 1907. He was considered to be the founder of the fields of cultural pedagogy and spiritual (anthroposophical) psychology. Most of the pedagogical scientists of the $20^{\text {th }}$ century - Gyula Kornis, Lajos Prohászka, Bogdan Nawroczynski - regarded him as the source of their own concepts; many of them attended his lectures in Berlin. From the contemporaries, Eduard Spranger's pedagogical framework and Georg Kerschensteiner's concepts of civic education and vocational school were appreciated and applied. Their views were determining in Central Europe, Germany, the historical Hungary and Poland as well.

Dilthey not only recognized the constantly changing 
nature of the goals of education, but this realization also helped him to formulate the necessity of the formal requirements of pedagogical sciences, which were based on experience and the teleological coherence of the spiritual life.

Gyula Kornis provided a detailed evaluation of Dilthey's views and concepts. The basic idea of his pedagogy and cultural philosophy is that one comes to know oneself through history. The historical world is the product of the objective spirit, which are the activities of creating values and realizing purposes. This product does not expire as spiritual content or culture, but it objectivates, lasts, and develops. [15]

The basis of Eduard Spranger's theory is humanism; the unfolding of the full power of man. His principle: intellectual knowledge and literacy is what protects man from half-literacy and simplification. Intellectual life, the spirit itself is the objective culture, which comes into existence by the realization of values through history. Experience and creating values during the cultural activity of man shapes him into becoming a personality. The most important goal of Spranger is to develop cultural philosophy, a science of values, and to establish a scientific theory of education called cultural pedagogy.

The impact of the work of scholars practicing spiritual knowledge was significant in Central Europe. In Germany, Georg Kerschensteiner's and S. Hessen's; in Hungary Mór Kármán’s, Ernő Finánczy’s, Gyula Kornis’s, Ákos Pauler's, Lajos Prohászka's, Ödön Weszely's; in Poland Twardowski's, Bogdan Nawroczynski's and Suchodolski's pedagodical concepts should be appreciated based on their approach to culture and literacy, methods of cultural transmission, and the way they define their goals.

\subsection{Universal and Instrumental Values}

Georg Kerschensteiner was the most popular scientist and educator of the first third of the $20^{\text {th }}$ century. He developed the theory of civic education and was a representative of cultural pedagogy. He was intent on unifying civic and moral education. He based his approach on the idea that since the social order is always decisive, the goals and tasks of education are subordinate to it. [26] He defined the notion of cultural learning as the center of his theory of pedagogy. Literacy is the goal and result of the process of cultural learning; a morally autonomous literate personality.

The development of concept of culture that is based on the theory of values is the result of Gyula Kornis's work. He unified the then-current theories of the pedagogy of values and cultural pedagogy, both originated in the philosophy of values. In Gyula Kornis's approach to culture there are two pillars of an evolving nation: enrichment and literacy. The basis of the fulfillment of the individual is culture; the aspiration of realizing ideas. The basis of culture from the perspective of value theory is: the true, the beautiful, the good and the divine, as the intent on the realization of ideal, eternal, and absolute values. These values can be equated with such elements of culture as science, art, morality, and religion. This culture is provided for the nation by the school, which transmits it to the next generation. Thus the radical and permanent renewal of the national society primarily depends on education. [15]

Lajos Prohászka believed that the purpose of cultural transmission is cultural learning, more specifically, its result: literacy. The notion of cultural learning is broader from the notion of education only by the fact that it is in effect throughout our whole life, while education, consisting of all pedagogical activities, is rather concerned with shaping the individual, most often being underage. [16] The process of cultural learning presupposes the formal training, which traditionally means the cultivation of skills. The formal training is intellectual because it aims at the development of the intellect and judgment. It is also expands to one's sentiment and will, since it applies for the whole person. The basis of the formal training is the spirit-cultivating curriculum. It is not the quantity of the curriculum, but its schematic content, which makes the student receptive to understand the intellectual work. The spirit-cultivating effect, the experience is what remains and lasts. This turns into permanent habit which cannot be substituted by any number of factual knowledge. The formal training of this schematic, spirit-cultivating curriculum enables the development of the mind and its activities, such as perspective, thinking, memory, imagination, will, and sentiment.

Ödön Weszely also believes that the purpose of education is literacy; the acquisition of culture. He claims that literacy, through culture, "becomes the science of human cultural learning, and the problems of pedagogy in most cases are related to the questions of literacy." [17] Culture extends to the whole of human life, thus education aims at completeness as well. As a consequence of this, Weszely devised besides the ideal (eternal) values as goals, the real and social goals as instrumental values, therefore he differentiates nine areas of culture. These are the embodiments of such ideal values as following: moral, religious, scientific, and artistic; and the others standing for the real and social purposes: bodily, technical, economic, social, civic cultural fields.

Kornis's, Prohászka's, and Weszely's psychology- and spiritual knowledge-based frameworks of cultural pedagogy can all be found in the views of the polish Bogdan Nawroczynski. The influence of the predecessors is the same among all of them. Nawroczynski attended the lectures of Dilthey in Berlin between 1905 and 1906, then the lectures of Wundt and Bart in Leipzig between 1906 and 1910. His most influential teacher was the father of the School of Lviv-Warsaw, K. Twardowski. In 1926, Nawroczynski established the Department of Pedagogy on the University of Warsaw. He shares his views on cultural pedagogy in many of his works. [18]

Nawroczynski also believes that the purpose of education is culture and the mental processes which promote cognition, comprehension and application of cultural goods. He also thinks that a person can accomplish being a cultural entity by practicing the ideal values: morality, aesthetics, and religion. 
Contrary to Weszely, Nawroczynski distinguishes eleven factors of a given society's spiritual culture: language, tradition, morality, religion, literature, music, art, science, philosophy, technology, social life. During the process of education, the teacher's purposeful activities, which result in making the person practice the ideal deeds, enables the individual to develop a personality. The personality has to meet the needs of society and culture. The task of pedagogy is education; the purpose of education is culture, cognition, comprehension and application of cultural goods in order to produce new ones. This is cultural learning-based education; it results in literacy - a conscious existence in culture. Culture: the reason of and motivation for a person's activities. [19]

The representatives of culture theory appointed self-development and morality as the main purpose of education. Their standard was a perfect ideal that people could never achieve, but each person had the same chance for reaching it. In the beginning of the $20^{\text {th }}$ century in Middle-Europe outstanding scholars and educational-politicians agreed that education is cultural transmission, and the purpose of education cannot be drawn from concrete facts, because in that case it would never be universal, exactly because of its factuality.

\section{The Perspective on Values of Reform Pedagogy}

At the turn of $19^{\text {th }}$ and $20^{\text {th }}$ century, due to economical and societal development, schooling expanded to the general public in Europe and in the United States. Meanwhile it was difficult for schools to adapt to the expectations of rapid changes regarding its devices, and methods. Reform pedagogists, the representatives of the "new educational" theories emphasized: the humanities prevail in the content of the curriculum. Education on primary schools is restricted; the methods of teaching and learning are out-of-date; and the teacher-student relationship is determined by the prevailing authoritarianism.

Most European schools were characterized by the newly defined educational goal, based on Herbart's pedagogy: a virtuous, disciplined citizen. On the other hand, the faster economic development in England, France, and the United States, provided a solid ground for the emergence of civil liberalism and democracy. Democracies are always accompanied by economic and political pluralism. All these contributed to the establishment of reform pedagogy, a new educational ideal and practice, which appeared in the $20^{\text {th }}$ century.

In contrary to traditional pedagogy, a new child-centered pedagogy was born in Europe and the United States. The two crucial fields were pragmatism and children studies. Pragmatism's new ideal of man was: an independent, free, active individual, who can decide for himself, can adapt to the continually changing environment, and is able to make his way in it. John Dewey implemented the philosophy of pragmatism in his new experimental school, which was different from the traditional in its structure, content, and devices. He believed that school has to be considered as a part of social life, which is in close interaction with home (family life), natural environment, business life, and a higher level of education in training for professions. In Dewey's school, children have to be educated so they can use their talents quickly, and evaluate their circumstances rightly. Their deeds and actions should be beneficial and effective for democracy and the conditions of modern production. [21]

The philosophy of children studies is that pedagogy has to be based on knowing the child. According to Édouard Claparède, the founder of Rousseau Institute, the child is the essential factor of education. Based on the law of functional autonomy, there is a need for a school which adjusts to the personal characteristics of a child [22]. That is why this school provides wider space for cheerfulness, activities, "free self-revelation", truly respects the child, and makes children enjoy work, so that it would become their lives' inducement. Also, by teaching the useful skills, it abolishes overexertion and relies on the individual abilities of a child.

We can examine the new educational purposes, tasks, methods, and features of new teacher-student relations in the works, school concepts, and views on communion of the representatives of reform pedagogy. The principles of a school "scaled for children" are: children' activeness and freedom, a complete facilitation of a child's personality and independency, and the realization of evolvement. These are all connected to an Italian scholar, Maria Montessori. Her actions in the "Children's House" became widely known not only in Europe, but overseas as well. According to Montessori, only the behavior that takes others' rights into account can limit children's freedom. To provide freedom and self-activity for children it is necessary to arrange a place, which is furnished appropriately for their age (children-sized furniture). In addition, adequate devices for the improvement of sensory organs (colorful rods, rolls, balls), and new educational attitude is needed. [23]

With the purpose of preparing for life, Ovide Decroly opened his private school in Brussels also at the beginning of the century (1907). The curriculum was built, according to children's interests, around two gradually expanding systems of knowledge: children's self-knowledge, and the knowledge concerning natural and social environment. Therefore it is essential to organize a classroom, equipped with original visual aids such as aquarium and plants; as well as the creation of collections, stamps, crops, minerals, etc. by children.

The stages of "new school" movements, named after Cecil Reddie, were England, Germany, the United States and France. These boarding "new schools" are primarily private schools. Institutions with their own councils are characterized by pedagogic principles which feature a daily routine of the unity of freedom and the sense of duty. The form of the council is constitutional monarchy. In this way, 
everyone has their own duties and roles. Teachers are the ministers and students represent citizens. The purpose of education is an autonomous, integrated personality. The process of teaching was realized by the harmony of tradition and modernity. In teacher-student relation, the teacher is a helping companion, while the student decides about the accomplishment of tasks, and is subject to the consequences. [24]

Along with the theories of cultural pedagogy, the representatives of reform pedagogy aimed for the improvement of society and school with their new educational concepts. In reform pedagogy they highlighted, that during the process of teaching-learning the main purpose of education became independence, freedom, activity and activeness of students. Contrary to intellectualism the intention of their approaches was to arrive at the desired results through focusing on individual needs, the interests of children, and practical experiences. The preferred content in the center of teaching-learning processes became the acquirement of practice-oriented and practical knowledge. The main objectives were the following: a healthy, free, righteous man (E. Key, E. Claparede); the need of adaptation to the changing environment (Dewey); the preparation of an independently living and acting man (M. Montessori, O. Decroly); ability for free judgments (R. Steiner). Furthermore, diverse collaboration, the importance of experience-based activities (C. Freinet); integrated personality, and using the devices of pedagogy to shape a self-conscious personal character (P. Petersen, László Nagy). [20] These tasks - as the main purposes to be realized during the process of teaching-learning - were criticized by the representatives of cultural pedagogy.

\subsection{The Contemporary Criticism of Reform Pedagogies}

Gyula Kornis examined the studies of European and American reform pedagogists, but he did not find any new ideas regarding the realization of educational purposes based on value theory. They were only repeating the ethics of Spencer, Mill, and Wundt. These pedagogical trends did not acknowledge the cultural conception of the value theory. The common intention of their tendencies was to expand the narrow formalism of school and to release man's creative personality. Their formation of thoughts and solutions was dominantly influenced by the rapid development of sciences; furthermore, by the efforts of establishing a different kind of state and social constitution, and the recognition of the new social needs.

As Kornis emphasized: the value of a pedagogical trend is determined by the number of opportunities that it provides for the realization of the notion of culture. He did not approve of the biological-ethical understanding of values, which based the ethical norms on biological facts. This ethical naturalism had only one elemental value: life is the supreme good. The only criterion of morality is the success in preserving life. Kornis admitted that biological factors are the conditions of morality, but these aspects are not suitable for deciding valuableness. "This mistake is the source of Nietzsche's immoralism, who based all values' reevaluation on the natural fact of the victory of the stronger over the weaker. This results in the pedagogy of wille zur macht, the brutal idea about educating for übermensch, borrowed from the arena." [15]

Kornis did not approve of the idea that pedagogy should only respect the cult of life, and progress, according to it, is nothing else than better adaptation. In addition, the purpose of it is mere life-pleasure; people should trust their instincts and act only in those cases which are beneficial for them. In Kornis's pedagogical view of values the beneficial principle cannot dominate. Biological factors are the conditions for unfolding the values, but they do not have the role of determining them. Like other natural sciences, biology is a neutral observer of the facts, just as psychology and sociology are the inactive observers of spiritual processes.

Educational purpose can only be appointed by the value theory, because the nature of factual laws is entirely different from the laws of values. The ideals and concepts of values influence the future, thus education must serve them.

In their pedagogy the pragmatists promoted the categories of „viability”, usefulness and practicability. They rejected all abstractions; focused their attention on reality, facts, and practical life. They turned away from the philosophy of values and saw the criterion of truth in its utility. The influence of pragmatism was extraordinary on the pedagogy of the time. From a pragmatist perspective, the questions of value theory gave the principal background of the pedagogical debates about the creation of curricula and the selection of materials for literacy. Kornis definitely states, that pedagogy has to be familiar with the nature of the notion of truth, because only this way can it decide about the exceptionally important question of human development: Which elements of literacy should be selected? This selection can only be carried out on the basis of perspectives of value theory. [15]

Kornis did not undervalue the development, importance, and achievements of biology, psychology, and sociology the empirical sciences - of his age, in fact, he examined them deeply. He adopted their results into his pedagogical concept, though he viewed the values conceived by them as material values.

Ödön Weszely considered the works of reform pedagogists - Decroly, Montessori, László Nagy, and others - significant. Based on children studies (pedology), they developed new methods for the recognition and education of children. This does not mean though, that the educator can settle for the studies of children and youth, because pedagogy has to aim for purposes, examine culture, determine values, and initiate norms. These are not given by the children studies. The scientific knowledge about children and the judgment of individual cases based on scientific studies, however, helps the educator on how to proceed in order to accomplish the purposes. [17]

Lajos Prohászka explicitly evaluated the contemporary 
practice of reform pedagogy in his work "The theory of education". [16] His principal statements are the following:

- Reform pedagogy denies all the previous theories and practices.

- It determines new "keywords", whose literature is substantial, but they only last for a few years.

- They discovered the "philosopher's stone"; the keywords are not hollow, but the constant debate resulted in uncertainty, "nothing seemed to be sure anymore".

- The methodological culture received more importance and at the same time the role of subjectivism increased.

\section{The Social Concepts - the Values of Community Education}

The necessity of the community education of an individual, the social importance of education, and the pedagogy theories promoting social determinism can be grouped to "social pedagogy". This new movement appeared at the turn of the 19th and 20th century.

Social sensibility in education science can be followed up from the renaissance - Feltre, Pestalozzi, Tessedik, Brunszvik, Don Bosco - until nowadays. Social pedagogy was established by Paul Natorp, who was the leading professor of the "Marburg school". He maintained that education can only be accomplished in and by a community. Educating the individual for the "service" of society, along with the sociological correlations, was emphasized in pedagogy. The issues of these concepts were: raising awareness of common laws and duties; improving the nation with the help of national education and common education (Sándor Imre); fulfilling the acquirement of general literacy (Sándor Karácsony); and the responsibilities of the state, considering the depravation of children of families living in adversity (Lipót Nemes).

The concepts of social improvement were seen in the education of respectful, working citizens; in the "power" of teachers; in the accomplishment of compulsory education; and in the enrichment of school conditions (workshops of industrial studies). The outcome was realized in the education of talented, indigent children; in the establishment of economic and specialized schools; and in the organization of child protection in schools. Their perspective on values closely fitted the principles of cultural pedagogy.

\section{Conclusions}

The chances provided by democracy of free choice of either high or low standards are the same for everyone. The duty of science is the in-depth examination and comparative investigation of a certain area, followed by publishing its results. The representatives of education politics have to acquire deep knowledge in order to formulate clear purposes.
Education is cultural transmission, its mission is to understand and assist the realization of the essence of qualitative adaptation. It is preceded by an independent, free choice of high standards.

This approach was constantly applied by the proper representatives of science. Education science evaluated the concepts of reform pedagogy supporting the advancement and enrichment of methodological culture; it conceived suggestions about the practice of community tasks of the individual, clarified and demonstrated the essential fact emphasized by all reform pedagogists: there is no productive work without discipline. The representatives of science supported pedagogical practice on continuing education, and assisted school meetings, which discussed the practical adaptability of certain concepts. Scholars also reconsidered the achievements of previous works and the possible need for a change. All these were compared with the stability of educational purposes which are transmitting the objectives of cultural pedagogy. These objectives consist of the eternal (absolute) values, which are still based on relevant value theories. The values serving the higher standards of people were also taken into consideration. The concepts of reform pedagogy provided safety not only for the interpretation of the role of the value components varying through ages and societies, but their transmission as tasks of education as well.

There is a lack of the functional institution-based theoretical and practical scientific debate between the theorists and functional specialists in this materialistic, estranged, overdriven, value-lost, shallowly happiness-seeker, atomized circumstance, where it is reduced for conferences at best with a minimal amount of functional specialists present.

All these can only partially cause that the objectives of the educational policies and higher education of the late socialist countries during the second half of the $20^{\text {th }}$ century were entirely missing the lessons which could be drawn from the results of both the school model of reform pedagogy and the principles of cultural pedagogy. The ideology-driven educational policy, which was based on materialistic world views, defined the biggest mistake of the pedagogy before World War II as: being based on religious world views, being idealistic, transmitting eternal values, overvaluing the antique culture.

This truly monotonous judgment of values can still often be found today in the lack of knowledge in our cultural heritage; the absence of qualitative cultural adaptation, as a consequence of half-literacy.

Deep knowledge, the transmission of universal values, and the qualitative adaptation of our cultural heritage is particularly important in democracy. Deliberate pedagogical work cannot exist without general/universal purposes and knowing the specific tasks varying by ages. Education is an eternal and historical category, which includes the continuous need of education; and innovation, as a constantly changing method and framework of purposes and devices. [28]

To the global challenges of the $21^{\text {st }}$ century we can only 
respond by forming an ethical, morally renewed, responsible behavior. The necessity of this and an option for realization is proved by the concept of István Bábosik, namely the educational model of constructive life management. István Bábosik believes that values are products, which fulfill double function: they improve the community and the individual as well. Accordingly to this, the individual's constructive life management is the educational or pedagogical value.

The two functional components of the constructive life management: community improving or moral component and self-developing are the elements upon which the successful life management is built. Constructive life management is realized in forms of behavior and activities. Shaping the forms of behavior and activities belong to the tasks of moral education, therefore it is socially valuable; while the forms of behavior which improve the individual, or self-development - those which follow the norms of intellectual/literal, aesthetic, healthy lifestyle - are the pedagogical conditions of an individual's improvement and success. [27]

Consequently, constructive life management is a kind of behavior shaping, which aims at recreating the values represented by the Greek culture - moral, mental, physical, aesthetic - and was transmitted into the European education. The outstanding scholar of $20^{\text {th }}$ century, Ernö Fináczy put this into words as following: the purpose of education is: "to enable the individual, and through them the social community (nation and humanity), to achieve moral perfection", by knowing and conscious realization of the absolute values: the truth, good and beautiful. [25]

\section{REFERENCES}

[1] Csaba Pléh- Gyula Kovács- Balázs Gulyás: Kognitív idegtudomány. [Cognitive neuroscience] Budapest, Osiris Kiadó, 2003. p. 26-27.

[2] Joseph Ratzinger: Isten és a világ. Hit és élet korunkban. [God and the world. Faith and life today] Budapest: Szent István Társulat. Az Apostoli Szentszék Könyvkiadója, 2004

[3] István Szijártó: „Egyöntetűségünk csodaszarvasa”. [“The steadiness of our miraculous deer"] Balaton Akadémia Kiadó, Keszthely, 2010. p. 34.

[4] Mária Kopp: A magatartástudomány alapkérdései. [The basic issues of behavioral science] In: Magatartástudományok. [Behavioral sciences] (eds. B. Buda, M. Kopp, E. Nagy) Medicina Kiadó, Budapest. p. 25.

[5] Kondrad Lorenz. A civilizált emberiség nyolc halálos büne. [The civilized man's eight deadly sins] (Translated by: Katalin Gellért) Cartaphilius Kiadó, Budapest, 2002, p. 42.

[6] Sándor Márai: Röpirat a nemzetnevelés ügyében. [Pamphlet on the issue of educating the nation] Első kiadás [First edition] 1942. Megjelent a Kalligram Könyv- és Lapkiadó Kft. Pozsony és Pesti Kalligram Kft. közös kiadásában [Published by Kalligram Könyv- és Lapkiadó Kft. and Kalligram Bratislava and Budapest Kft.], 2004. pp. 82-83.

[7] János Zlinszky: Korunk és a közjó. [Our times and common good] In Mélység és magasság. [Depth and height] Eds. M. Kováts-Német-Ferenc Egresits. Győr: NYME ACSJTF. 2002, pp. 8-9.

[8] Mária Kovátsné Németh: Módszertani kultúra a tanítóképzésben a 20. század első felében. [Methodological culture in teacher training during the first half of the $20^{\text {th }}$ century] Neveléstörténet, 2009, 6/issue 1-2, p. 41-42.

[9] Magyar Larousse Enciklopédia 2. kötet [2 ${ }^{\text {nd }}$ volume of Encyclopedia Hungarian Larousse] (Editors in chief: Éva Ruzsiczky and János Szálvai) Librairie Larousse, Paris, 1979 - Akadémiai Kiadó, Budapest, 1972. p. 579.

[10] János Apáczai Csere: Előszó az olvasóhoz. [Foreword to the reader] Apáczai Csere János üdvözli az igaz bölcsességre törekvő olvasót. [János Apáczai Csere welcomes the reader aspired to the true wisdom] In.: Mária Kovátsné Németh: Apáczai Csere János Magyar Encyclopaedia. Apáczai Kiadó, Celldömölk, 2004. p. 10.

[11] Mária Kovátsné Németh: Kultúra és nevelés. [Culture and education] Komárno: Felnőttképzési Intézet Kht. 2013, pp. 32-35.

[12] Albert Szent-Györgyi: Az örült majom. [The insane ape] Magvető Kiadó, Budapest, 1984. p. 24.

[13] Friedrich W. Kron (2003): Pedagógia. [Pedagogy] Budapest: Osiris Kiadó. p. 24-25.

[14] Péter Balogh: lecture on II. Egyetemes Tanítógyülés [2 $2^{\text {nd }}$ Universal Gathering of Teachers], 1896.

[15] Gyula Kornis: Értékelmélet és pedagógia. [Value theory and pedagogy] Bp. 1913. pp. 194-197.

[16] Lajos Prohászka: Az oktatás elmélete. [The theory of education] Kiadja [Published by] Országos Középiskolai Tanáregyesület, Budapest. 1937. pp. 26 - 29.

[17] Ödön Weszely: Pedagógia. [Pedagogy] Második teljesen átdolgozott kiadás. [Second fully improved edition] Budapest: Révai Kiadás. 1937. pp. 45-50.

[18] B. Nawroczynski: Az oktatás alapelvei, [Basic principles of education], Zasady nauczania, Warszawa, 1930.; Szellemi élet. A kultúrfilozófia vázlata, [Mental life. The draft of cultural philosophy] Kraków-Warszawa, 1947, Translated by: A. Barátka.

[19] B. Nawroczynski: Wspólczsne prady pedagogiczne. In: B. Nawroczynski: Dziela Wybrane. Tom I. Wydawnictwa Szkolne i Pedagogiczne, Warszawa, 1987, 483 - 548. Dorabianie sie struktury duchowej. In: Uo. 122 123.Ustopniowanie celów nauczania. In: ibid. 36 - 38. Ideal wyksztalcenia. In: ibid. pp. $87-88$.

[20] Mária Kováts-Németh: Az erdőpedagógiától a környezetpedagógiáig. Pécs: Comenius Kft. 2010.

[21] John Dewey: Az iskola és társadalom. [The School and Society] (1912) Re-published: Kovátsné Németh Mária alkotószerkesztő: Iskolafejlesztés a XX. században. [The development of school in the $20^{\text {th }}$ century] Pécs, Comenius Kft.. 2007. pp. 49-56.

[22] Édouard Claparède: Élet-e a nevelés, vagy az életre való 
felkészítés. [Is education life, or the preparation for life] In.: A funkcionális nevelés. [Functional education] Bp.1974.

[23] Mária Montessori: Gyermek és nevelés. [Child and education] In: Az ember nevelése. [Education of man] Budapest, Tankönyvkiadó, 1978. Re-published: Kovátsné Németh Mária alkotószerkesztő: Iskolafejlesztés a XX. században. [The development of school in the $20^{\text {th }}$ century] Pécs, Comenius Kft.. 2007. pp. 71-74.

[24] Mária Kovátsné Németh: Pedagóiai rendszerek, elvek és értékek az ezredfordulón. [Pedagogical systems, principles and values on the turn of the millennium] Pécs: Comenius Bt. Nyomda. 2001, pp. 98-100, 103, 105, 106-108.

[25] Ernő Finánczy: Elméleti pedagógia [Theoretical pedagogy], Bp. 1937. In.: Mária Kovátsné Németh: Pedagógiai rendszerek, elvek és értékek az ezredfordulón. [Pedagogical systems, principles and values on the turn of the millennium] Comenius Bt. Pécs, 2001. p. 10.

[26] Georg Kerschensteiner: A jövő iskolája a munkaiskola. [The school of the future is vocational school] In.: Mária Kovátsné Németh: Iskolafejlesztés a XX. században [The development of school in the $20^{\text {th }}$ century] Comenius Kft. - Pécs, 2007, p. 258

[27] István Bábosik: Neveléselmélet [Educational Theory] Osiris Kiadó, Budapest, 2004. p.12-14.

[28] Pedagógiai Lexikon 3. kötet [Pedagogical Lexicon $3^{\text {rd }}$ volume]. Editor in Chief: Sándor Nagy. Budapest, Akadémiai Kiadó, 1978. p. 279. 